\title{
Healthcare providers' practice and attitude towards abortion service provision in Gulu city, Northern Uganda
}

Francis Pebolo Pebalo ( $\sim$ pebalopebolo@gmail.com )

Gulu University Faculty of Medicine https://orcid.org/0000-0002-1205-1150

\section{Auma Anna Grace}

Lira University

Obol James Henry

Gulu University Faculty of Medicine

\section{Research}

Keywords: Abortion, Attitude, Beliefs Abortion Laws, Knowledge

Posted Date: August 18th, 2020

DOI: https://doi.org/10.21203/rs.3.rs-57258/v1

License: (c) (i) This work is licensed under a Creative Commons Attribution 4.0 International License.

Read Full License 


\section{Abstract}

Background: Unsafe abortion is a growing public health problem concern globally despite being preventable. The World Health Organization estimates that about 20 million pregnancies results into unsafe abortion globally. The proportion of unsafe abortion has been increasing with developing countries contributing about $97 \%$ of unsafe abortions cases including Uganda. Unsafe abortion is among the four leading causes of pregnancy related mortality, injuries, and disability globally. The restrictive abortion laws and religious situation make abortion a highly controversial social issue in Uganda leading to high stigma in the society, and a majority of the healthcare providers are reluctant to perform an abortion even if indicated for fear of possible legal consequences.

Methods: We conducted survey among health worker about knowledge of complications, practice, and attitudes of induced abortion between September and November 2019 among 252 healthcare providers in Gulu Municipality, Northern Uganda. Multivariate analysis showed associations between healthcare providers' characteristics and adequate knowledge about abortion complications. Ordinary least square regression analysis found associations between providers' characteristics and their intention for general support, generally not in support, conditional support for abortion provision, as well as their personal attitudes and beliefs against or towards abortion provision.

Results: The mean attitudinal score for generally in support, generally not in support, conditional in support, personal attitude, and beliefs against and toward abortion provision were 2.80, 2.71, 2.86, 3.239, and 3.35 respectively. Participants who were married and practice Anglican religion were more likely to have good knowledge of abortion complications, p-values 0.035 , and 0.042 respectively, meanwhile participants who were employed in faith-based facilities were more likely to have poor knowledge of abortion complications p-value 0.002 .

Conclusion: Ministry of Health and stakeholders need to provide training of health workers to improve quality of abortion services. Medical training institutions should ensure that students understand the laws and responsibilities that govern their professional actions with respect to abortion care regardless of their personal views, beliefs, and attitudes.

\section{Background}

Unsafe abortion is a growing public health problem globally despite being preventable (1). The World Health Organization (WHO) estimates that about 20 million pregnancies results into unsafe abortion globally (1) and the proportion of unsafe abortion has been increasing (2-4) with developing countries contributing about $97 \%$ of unsafe abortions cases $(3,4)$. Unsafe abortion is among the four leading causes of pregnancy related mortality, injuries, and disability globally $(1,5)$. Sub-Saharan Africa (SSA) contributed $62 \%$ of the global pool of unsafe abortions cases(3). A Unsafe abortion is a significant contributor to maternal mortality accounting for about $13 \%$ of total maternal mortality worldwide(1) with 
Eastern Africa having the highest proportion of maternal mortality as a result of unsafe abortion at $18 \%$ (1).

In Uganda, research shows that about $30.2 \%$ of adolescents and $43.1 \%$ non-adolescents sought abortion services from medical professional (6) A study done in Uganda found that in 2013, a total of, 93,265 or (72\%) of the women who sought treatment for abortion complications were treated for unsafe abortion complications (7) meanwhile in Kenya, 119,502 or $76 \%$ of women who were treated in health facilities for abortion complications were as result of unsafe abortions in 2012 (8). Within Eastern Africa, there is variations in unsafe abortion rate with Uganda and Kenya have the highest annual rate of hospitalization for treatment of unsafe abortion at 12 per 1,000 women aged $15-49$ years $(7,8)$, Rwanda at 7 per 1,000 women aged 15-44 years (9) and Tanzania at 5.9 per 1,000 women aged 15-49 years (10). Furthermore, study shows that in 2013 , about $13 \%$ of total pregnancies in Uganda resulted into abortion (7). In Uganda, an estimated $26 \%$ of the maternal mortality in 2008 was caused by unsafe induced abortions (11). The high abortion rates in Uganda can be attributed to the low Contraceptive Prevalence Rate(CPR) (35\%), high unmet need for family planning (28\%) and high Total Fertility Rate (TFR) (5.4) (12) which results into about $44 \%$ of pregnancies being unwanted (13).

Unsafe abortion has several consequences which includes morbidity, mortality, disability as well as economic consequences to the woman and her immediate family but also the direct cost of providing medical care during hospitalization (2). In Uganda, abortion is severely restricted and is highly a controversial social issue based on religious grounds (14). The restrictive nature of abortion laws in Uganda has made abortion a clandestine practice (15) with women who can pay for the service of qualified provider will receive safe abortion services while adolescents and poor or rural women often obtain abortion services from unskilled person or induce the abortion by themselves (2).

In Uganda, the Penal Code of 1950 penalizes anyone who abort a pregnancy or contributed to the procurement of abortion except when the intention was to save the woman's life (7). The Uganda Ministry of Health has lifted restriction for induced abortion under circumstances such as when the pregnant woman is HIV positive, the pregnancy is a result of rape, defilement or incest but must be performed in health centre IV or a hospital (7). The unclear and ambiguous interpretation of the laws on induced abortion in the country has created stigmatization among the skilled healthcare providers thereby making them reluctant to perform safe abortion for fear of the possible legal consequences.

As a precursor for a wider stakeholder engagement, this study was conducted to solicit the views of health workers about abortion. Therefore, this study aimed to determine knowledge, attitudes, and practice of induced abortion among health workers who were working in Gulu Municipality.

\section{Methods}

\section{Study design, settings, and participants}


The study was a cross-sectional survey conducted between September and November 2019 in the Gulu Municipality in Gulu district (now Gulu City as of 1st July 2020) located about 360 km north of Kampala, the capital city of Uganda. It is divided into four administrative divisions and each division having 62 a public health center level III. In addition, there are four hospitals within Gulu Municipality, two being Public hospitals, and the other two private hospitals; Gulu Regional Referral Hospital and Gulu 4th Division Military Hospital are both public hospitals. Gulu Regional Referral Hospitals also serve as a Teaching Hospital for Gulu University and other paramedical institutions. St Mary's Hospital Lacor, the largest general hospital in Northern Uganda is a private non for- profit faith-based belonging to the Catholic mission under Gulu Archdiocese, also serves as a Teaching Hospital for Gulu University while Gulu Independent Hospital is a private for-profit hospital. All hospitals provide both curative and preventive healthcare services. There are several private clinics within the municipality as well as other private non for profit Non-Governmental Health Centers.

The research participants comprised of doctors, nurses, midwives, and clinical officers who were working in health facilities within Gulu Municipality.

\section{Sample Size And Sampling Procedure}

The sample size was calculated using a formula for a single population proportion with a finite population.

$$
\text { Sample size, } \mathbf{n}=\mathrm{N} * \frac{\frac{Z^{2} * \boldsymbol{p} *(1-p)}{e^{2}}}{\left[N-1+\frac{Z^{2} * p *(1-p)}{e^{2}}\right]}
$$

where $\mathrm{N}$ is the population size of health workers in Gulu Municipality (600), $\mathrm{n}$ is desired sample size, $\mathrm{Z}$ is the critical value of the normal distribution at $95 \%$ confidence level (1.96), $p$ is the proportion of health workers who have ever been approached for abortion services, set at 0.5 since the proportion is unknown in this community and e is the margin of error set at 0.05 . This gives a sample size of 235 health workers. We increased the sample size by $5 \%$ to cater for non-response or withdrawal of consent giving us final sample size of 247 health workers.

Participants were consecutively sampled from each health facility.

\section{Data Collection Procedure And Instrument}

Data was collected using a self-administered structured questionnaire written in English. The questionnaire had six parts. The first section of the questionnaire captured demographic characteristics of research participants. The second section obtained information about the knowledge of complications related to unsafe abortion. The third section of the questionnaire is about the opinion on how to avoid complications related to unsafe abortion. The fourth section of the questionnaire obtained information about participants' opinions on people who are more likely to seek abortion services. The fifth section of the questionnaire sought information about participants' practice on induced abortion and the last 
section of the questionnaire obtained information about participants' attitudes towards abortion using a Likert like attitudinal score adopted from a study conducted among South African medical students (16). The South African study used three sub-scales with 25 total items. A modification was done by dropping out three items that were not relevant for our participants and these 22 items were regrouped into five sub-scales.

\section{Operational definitions of outcomes measured,}

Knowledge of complications related to unsafe abortion was measured using seven items questions with a "yes" or "no" response. Each correct response was awarded one mark while each wrong response was given zero mark. The scores were summed, and the mean score was used to categorized participants as having adequate knowledge if the participant's total score was equal or above the mean score or inadequate knowledge if the participant's total score was below the mean score.

Attitudes were assessed using a 22-statement item measured on a 5-point Likert scale (5-Strongly Agree, 4-Agree, 3-No Opinion, 2-Disagree, 1-Strongly Disagree). The attitudinal scale was divided into five subscales with the first section was generally in support of abortion provision measured using 3 items. The second section was generally not in support of abortion provision measured using two items. The third section measured conditional support for abortion provision, using nine items. While the fourth section measures personal attitudes or beliefs against abortion provision using six items and the last section measure personal attitudes or beliefs towards abortion provision using two items. We summed up participants' scores from each of the sub-scale and the averages were calculated. Participants who scored equal or above the means were considered as having positive attitudes while participants who scored below the means were categorized as having negative attitudes. The internal reliability of each the sub-scale was calculated using Cronbach's alpha statistics and found to be $0.75,0.58,0.76,0.71$ and 0.44 for Generally in Support, Generally not in support, conditionally in support, personal attitude or beliefs towards and personal attitudes and beliefs against abortion provision respectively.

\section{Quality Control}

We pretested the questionnaire among 10 health workers who were working in Anaka general hospital to ensure that the wordings were well understood and correct any errors in word meaning. We trained research assistants on research ethics, privacy, data collection tool, and consent procedures. The Principal Investigator (PI) monitored data collection and cross-checked that the questionnaires were correctly filled. Data were entered twice in a database, merged, and cleaned before data analysis.

\section{Data Management And Analysis}

We used EpiData version 4.6.0.2 to create a database for this study and data was exported to Stata 16 for analysis. Categorical variables were displayed in a table together with their frequencies and percentages. Continuous variables were categorized using means and presented with their ranges, standard deviation, and means. Multivariate logistic regression using entered methods was used to 
assess the relationship between adequate knowledge for complication related to unsafe abortion and participants' demographic characteristics. Any factor with $p$-value $\geq 0.05$ was taken as a significant predictor of adequate knowledge about complications related to unsafe abortion.

We used ordinary least-square regression methods to assess for an association between research participants' demographic characteristics and attitudes as measured using the five scales (Generally in support to abortion provision; Generally, not in support to abortion provision; Conditional support for abortion provision; Personal attitudes toward abortion provision and Attitude against abortion provision). All participant demographic characteristics were included as a covariate in the analysis.

\section{Ethical Approvals}

Gulu University Research Ethics Committee approved the study under number GUREC-079-19. and each individual research participants provided written informed consent before participation in the study. Administrative clearances were granted by Gulu Regional Referral Hospital ethical committee correspondence number ADM/2017-18/001 and St Mary's Hospital Lacor ethical boards with administrative clearance number LHIREC Adm 022/09/19. Marie Stopes Uganda provided an email clearance, other Health centres, and hospitals provided administrative clearance verbally by each institutional head before we recruited the participants into the survey. All information collected in this study is being kept with strict confidentiality and only accessible by the research team.

\section{Results}

\section{Demographic characteristics}

A total of 252 out of 300 health care providers completed the self-administered questionnaire giving a response rate of $84 \%$; of these, $84 \%$ were below 40 years of age, and $68 \%$ were female. The majority were Government employees (40\%) while $30 \%$ were employed in faith-based health facilities, $(18 \%)$ employed in Private for-profit facilities, 26(10\%) in Private not for Profit Non-Governmental Health facilities and $6(2 \%)$ were employed in both Private and Government Health facilities. More than half of the respondents were Catholic believers (56\%) and up to $80 \%$ had a strong affiliation to their religion. Nurses and midwives comprised a majority with $85(34 \%)$ and $86(34 \%)$ respectively; while $30(12 \%)$ were Clinical Officers, $26(10 \%)$ were Doctors, and $24(10 \%)$ other health care cadres (pharmacists, Anaesthetists). More than $1 / 3(38.6 \%)$ of the respondents have been in practice for at least six years (Table 1$)$. 
Table 1

Demographic characteristics

\begin{tabular}{|c|c|c|}
\hline Variables & Frequency & $\%$ \\
\hline \multicolumn{3}{|l|}{ Gender $(n=252)$} \\
\hline Male & 80 & 32 \\
\hline Female & 172 & 68 \\
\hline \multicolumn{3}{|l|}{ Age group $(n=252)$} \\
\hline Less than 20 years & 25 & 10 \\
\hline $20-29$ years & 109 & 43 \\
\hline $30-39$ years & 78 & 31 \\
\hline 40 and above years & 40 & 16 \\
\hline \multicolumn{3}{|l|}{ Marital status $(n=252)$} \\
\hline Single/Separated/Widowed & 101 & 40 \\
\hline Cohabiting & 35 & 14 \\
\hline Married & 116 & 46 \\
\hline \multicolumn{3}{|l|}{ Religion $(n=252)$} \\
\hline Catholic & 140 & 56 \\
\hline Anglican & 59 & 23 \\
\hline Born again Christian & 42 & 17 \\
\hline others (Muslim/Seventh Days Adventists/Nonbelievers) & 11 & 4 \\
\hline \multicolumn{3}{|l|}{ Religious beliefs $(n=251)$} \\
\hline Very strong & 200 & 80 \\
\hline Somewhat strong & 27 & 11 \\
\hline Neither strong nor weak & 24 & 9 \\
\hline \multicolumn{3}{|l|}{ Education level $(n=252)$} \\
\hline Certificate & 97 & 39 \\
\hline Diploma & 99 & 39 \\
\hline Degree & 56 & 22 \\
\hline \multicolumn{3}{|l|}{ Employment status ( $n=251$ ) } \\
\hline Employed in Government only & 100 & 40 \\
\hline
\end{tabular}




\begin{tabular}{|lll|}
\hline Variables & Frequency & $\%$ \\
\hline Employed in NGO Health Centre & 26 & 10 \\
\hline Employed in Private For-Profit Hospital & 44 & 18 \\
\hline Employed in private non-for-Profit Hospital & 75 & 30 \\
\hline Employed in Both Government and Private Hospitals & 6 & 2 \\
\hline Type of health care provider $(\mathbf{n}=\mathbf{2 5 1})$ & & \\
\hline Nurse & 85 & 34 \\
\hline Midwives & 86 & 34 \\
\hline Doctor & 26 & 10 \\
\hline Clinical Officer & 30 & 12 \\
\hline Others & 24 & 10 \\
\hline Numbers of years working $(\mathbf{n}=\mathbf{2 5 1})$ & & \\
\hline Less than one $(1)$ year & 45 & 17.9 \\
\hline 1 to 5 years & 109 & 43.4 \\
\hline 6 to 10 years & 51 & 20.3 \\
\hline 11 years and above & 46 & 18.3 \\
\hline
\end{tabular}

\section{Knowledge Of Abortion Complications And Prevention}

Most of the respondents were aware of the complications of unsafe abortion; $87 \%$ knew that unsafe induced abortion causes bleeding, infertility, (81\%) infection ( $90 \%)$, chronic pelvic pain $(66 \%)$, psychological trauma (69\%), and deaths (81\%) (Table 2).

Regarding their knowledge on prevention of complications arising from unsafe abortion, majority of the respondents $215(85 \%)$ believe that health education creates awareness, therefore, preventing complications of abortion, while 187(74\%) knew that using modern contraceptives would prevent abortion complications, only $103(41 \%)$ knew that avoiding sex before marriage would prevent abortion complications, about $93(37 \%)$ knew that seeking safe abortion prevents abortion complications, $116(47 \%)$ knew that allowing the pregnancy to go to term would prevent abortion complications, and 98(39\%) knew that legalizing abortion would prevent abortion complications, (Table 2). 
Table 2

Knowledge of abortion complications and prevention

\begin{tabular}{|c|c|c|}
\hline Variables & Frequency & $\%$ \\
\hline \multicolumn{3}{|c|}{ Complications related to unsafe abortions } \\
\hline \multicolumn{3}{|c|}{ Bleeding $(n=252)$} \\
\hline No & 32 & 13 \\
\hline Yes & 220 & 87 \\
\hline \multicolumn{3}{|c|}{ Infertility ( $n=252)$} \\
\hline No & 48 & 19 \\
\hline Yes & 204 & 81 \\
\hline \multicolumn{3}{|c|}{ Infections ( $n=252$ ) } \\
\hline No & 26 & 10 \\
\hline Yes & 226 & 90 \\
\hline \multicolumn{3}{|c|}{ Uterine perforation $(n=252)$} \\
\hline No & 57 & 23 \\
\hline Yes & 195 & 77 \\
\hline \multicolumn{3}{|c|}{ Chronic Pelvic pain $(n=252)$} \\
\hline No & 86 & 34 \\
\hline Yes & 166 & 66 \\
\hline \multicolumn{3}{|c|}{ Death $(n=252)$} \\
\hline No & 47 & 19 \\
\hline Yes & 205 & 81 \\
\hline \multicolumn{3}{|c|}{ Psychological trauma $(n=252)$} \\
\hline No & 78 & 31 \\
\hline Yes & 174 & 69 \\
\hline \multicolumn{3}{|c|}{ Preventive measures } \\
\hline \multicolumn{3}{|c|}{ Use of modern contraceptives $(n=252)$} \\
\hline No & 65 & 26 \\
\hline Yes & 187 & 74 \\
\hline
\end{tabular}




\begin{tabular}{|lll|}
\hline Variables & Frequency & $\%$ \\
\hline No & 37 & 15 \\
\hline Yes & 215 & 85 \\
\hline Avoiding sex if unmarried $(\mathbf{n = 2 5 2})$ & & \\
\hline No & 149 & 59 \\
\hline Yes & 103 & 41 \\
\hline Use of abortion services $(\mathbf{n = 2 5 2})$ & & \\
\hline No & 159 & 63 \\
\hline Yes & 93 & 37 \\
\hline Give birth once pregnant $(\mathbf{n = 2 4 8})$ & & \\
\hline No & 132 & 53 \\
\hline Yes & 116 & 47 \\
\hline Abortion legalization $(\mathbf{n = 2 5 2})$ & & \\
\hline No & 154 & 61 \\
\hline Yes & 98 & 39 \\
\hline
\end{tabular}

\section{Category Of People More Likely To Seek Abortion Services}

A majority of the respondents $222(88 \%)$ reported that girls in schools are the ones who are more likely to seek for termination of pregnancy, while $173(69 \%)$ reported unmarried couple being more likely to seek abortion services, and $168(67 \%)$ reported that unfaithful wives are more likely to seek for abortion services. Nearly half of the respondents $120(48 \%)$ reported couples who fail to use family planning methods as well as those who have reached their family size $89(35 \%)$ and of poor socio-economic status $66926 \%$ ), we're likely to seek abortion services (Table 3). 
Table 3

Category of people are most likely to seek abortion services

\begin{tabular}{|c|c|c|}
\hline Variables & Frequency & $\%$ \\
\hline \multicolumn{3}{|c|}{ Unmarried couples $(n=252)$} \\
\hline Yes & 173 & 69 \\
\hline No & 79 & 31 \\
\hline \multicolumn{3}{|c|}{ Couples who failed to use family planning methods $(n=252)$} \\
\hline Yes & 120 & 48 \\
\hline No & 132 & 52 \\
\hline \multicolumn{3}{|c|}{ Unfaithful wives seeking to conceal the pregnancy $(n=252)$} \\
\hline Yes & 168 & 67 \\
\hline No & 84 & 33 \\
\hline \multicolumn{3}{|c|}{ Couples who have reached their family size $(n=252)$} \\
\hline Yes & 89 & 35 \\
\hline No & 163 & 65 \\
\hline \multicolumn{3}{|c|}{ Couples with poor socioeconomic status $(n=252)$} \\
\hline Yes & 66 & 26 \\
\hline No & 186 & 74 \\
\hline \multicolumn{3}{|c|}{ Girls still in school or institutions of learning $(n=252)$} \\
\hline Yes & 222 & 88 \\
\hline No & 30 & 12 \\
\hline
\end{tabular}

\section{Practice On Induced Abortion}

Majority of the respondents $218(87 \%)$ reported to have been approached by the client (s) seeking abortion services, of these, 209 (84\%) have been approached by about 1 to 5 clients in a month, with 200 $(79 \%)$ have not used any method of pregnancy termination. Nearly half $(49 \%)$ suggests a change in the abortion provision laws of Uganda (Table 4). 
Table 4

Practice on induced abortion

\begin{tabular}{|c|c|c|}
\hline Variables & Frequency & $\%$ \\
\hline \multicolumn{3}{|c|}{ Have ever been approached by a client seeking abortion services $(n=252)$} \\
\hline Yes & 218 & 87 \\
\hline No & 34 & 13 \\
\hline \multicolumn{3}{|c|}{ How often do you get cases of clients seeking abortion services? $(n=248)$} \\
\hline $1-5$ cases in a month & 209 & 84 \\
\hline $6-10$ cases in a month & 13 & 5 \\
\hline More than 10 cases a month & 26 & 11 \\
\hline \multicolumn{3}{|c|}{ Have ever used any common practice to induce abortion $(n=252)$} \\
\hline Yes & 52 & 21 \\
\hline No & 200 & 79 \\
\hline \multicolumn{3}{|c|}{ Do you have anyone to seek permission before performing abortion services? ( $n=248$ ) } \\
\hline Yes & 141 & 57 \\
\hline No & 107 & 43 \\
\hline \multicolumn{3}{|c|}{ Do you suggest a change in the law on abortion in Uganda? $(n=250)$} \\
\hline Yes & 123 & 49 \\
\hline No & 127 & 51 \\
\hline
\end{tabular}

The Attitude Of Respondents On Abortion Service Provision 
Table 5

Attitudinal scores about abortion

Statements

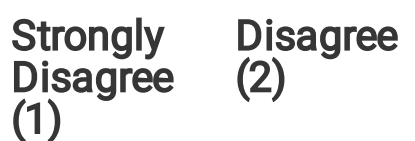

No

Opinion

(3)

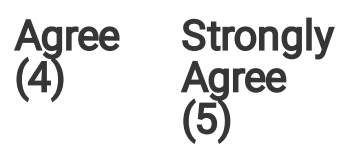

General support for abortion provision (alpha $=0.75$, mean score $=$

$2.8,95 \% \mathrm{Cl} 2.65-2.99)$

General support for the provision of safe,

voluntary abortion should be made legal and

accessible $(n=251)$.

$89(35) \quad 33(13) \quad 14(6)$

50

(20)

$65(26)$

The government should be responsible for

providing abortions as a part of the

$88(35) \quad 43(17) \quad 21(9)$

46

(18)

$53(21)$

minimum healthcare package $(n=251)$.

A woman should have the right to decide for

herself whether or not to have an abortion ( $\mathrm{n}$

$87(35)$

$44(17) \quad 12(5)$

34

(13)

$75(30)$

= 252).

Generally not in support for abortion provision (alpha $=0.58$, mean $=2.71,95 \% \mathrm{Cl} 2.54-$ 2.87)

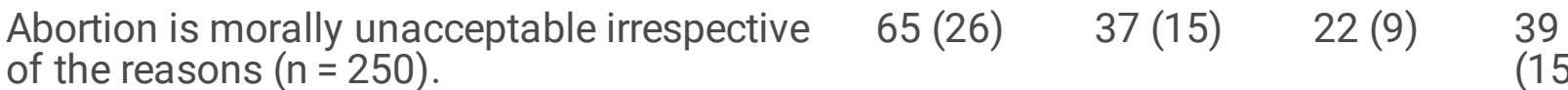

Abortion should not be provided for any

reason $(n=249)$.

$107(43) \quad 69(28) \quad 10(4)$

22

(9)

$87(35)$

$(15)$

$41(16)$

Conditional support for abortion provision (alpha $=0.76$, mean score $=2.86,95 \% \mathrm{Cl} 2.75-2.96$ )

Abortion provision should be legal if the woman's physical health is endangered by

$30(12) \quad 13(5)$

$5(2)$

43

(17)

161

the pregnancy $(n=252)$.

Abortion should be legal if the woman's

mental health is endangered by the

pregnancy $(\mathrm{n}=252)$.

$38(15)$

$31(12)$

$20(8)$

44

(18)

119

(47)

Abortion should be legal if the woman is not

married $(n=252)$.

$152(60) \quad 44(18) \quad 21(8)$

10

(4)

$25(10)$

Abortion provision should be legal if the family (or woman) cannot afford to raise the child $(n=252)$.

$128(51) \quad 51(20) \quad 17(7) \quad \begin{array}{ll}24 \\ (9)\end{array}$

$32(13)$

(9)

(64)

Abortion provision should be legal if the fetus shows signs of serious congenital defect or malformation $(n=252)$.

\begin{tabular}{lllll}
\hline $38(15)$ & $15(6)$ & $20(8)$ & $\begin{array}{l}44 \\
(17)\end{array}$ & $\begin{array}{l}135 \\
(54)\end{array}$ \\
& & & & \\
$66(26)$ & $57(23)$ & $28(11)$ & $\begin{array}{l}34 \\
(13)\end{array}$ & $67(27)$ \\
\hline $88(35)$ & $57(23)$ & $28(11)$ & $\begin{array}{l}26 \\
(10)\end{array}$ & $52(21)$ \\
\hline
\end{tabular}

Abortion provisions should be legal if the woman was raped $(n=252)$.

Abortion provision should be legal if the pregnancy was a result of incest $(n=251)$. 


\begin{tabular}{|llllll|}
\hline Statements & $\begin{array}{l}\text { Strongly } \\
\text { Disagree } \\
(\mathbf{1})\end{array}$ & $\begin{array}{l}\text { Disagree } \\
(\mathbf{2})\end{array}$ & $\begin{array}{l}\text { No } \\
\text { Opinion } \\
\mathbf{( 3 )}\end{array}$ & $\begin{array}{l}\text { Agree } \\
(\mathbf{4})\end{array}$ & $\begin{array}{l}\text { Strongly } \\
\text { Agree } \\
\text { (5) }\end{array}$ \\
\hline $\begin{array}{l}\text { Abortion provisions should be legal if the } \\
\text { pregnancy would mean that the mother had } \\
\text { to drop out of school }(\mathrm{n}=251) .\end{array}$ & $120(48)$ & $52(21)$ & $16(6)$ & 29 & $34(14)$ \\
$\begin{array}{l}\text { Abortion provision should be legal if the } \\
\text { pregnancy was unplanned, and the woman } \\
\text { does not want to be pregnant }(\mathrm{n}=252) .\end{array}$ & $117(46)$ & $48(19)$ & $21(8)$ & $\begin{array}{l}32 \\
(13)\end{array}$ & $34(14)$ \\
\hline
\end{tabular}

Personal belief or attitude against abortion provision (alpha $=0.71$, mean score $=3.23,95 \% \mathrm{Cl} 3.12-$ 3.35)

\begin{tabular}{|c|c|c|c|c|c|}
\hline $\begin{array}{l}\text { I prefer not to perform an abortion under any circumstances ( } \mathrm{n} \\
=252 \text { ). }\end{array}$ & $\begin{array}{l}62 \\
(25)\end{array}$ & $\begin{array}{l}44 \\
(17)\end{array}$ & $\begin{array}{l}25 \\
(10)\end{array}$ & $\begin{array}{l}46 \\
(18)\end{array}$ & $\begin{array}{l}75 \\
(30)\end{array}$ \\
\hline $\begin{array}{l}\text { I would not refer a patient for abortion under any circumstances } \\
(\mathrm{n}=252) \text {. }\end{array}$ & & & $\begin{array}{l}22 \\
(9)\end{array}$ & & $\begin{array}{l}49 \\
(20)\end{array}$ \\
\hline $\begin{array}{l}\text { If a female patient } r \\
\text { discourage her from }\end{array}$ & & 23 & 20 & & $\begin{array}{l}103 \\
(41)\end{array}$ \\
\hline $\begin{array}{l}\text { I would } \\
\text { perform }\end{array}$ & & & & & $\begin{array}{l}80 \\
(32)\end{array}$ \\
\hline $\begin{array}{l}\text { I think I would be discriminated a } \\
\text { provided abortions to women ( } \mathrm{n}\end{array}$ & & & & & $\begin{array}{l}77 \\
(31)\end{array}$ \\
\hline $\begin{array}{l}\text { Health care providers who conscientiously object to abortio } \\
\text { should be allowed to refuse to perform abortions }(n=252) \text {. }\end{array}$ & $\begin{array}{l}45 \\
(18)\end{array}$ & $\begin{array}{l}32 \\
(13)\end{array}$ & $\begin{array}{l}39 \\
(15)\end{array}$ & $\begin{array}{l}59 \\
(23)\end{array}$ & $\begin{array}{l}77 \\
(31)\end{array}$ \\
\hline
\end{tabular}

Personal attitudes/beliefs toward abortion provision (alpha $=0.44$, mean $=3.19,95 \% \mathrm{Cl} 3.04-3.35$ )

\begin{tabular}{|c|c|c|c|c|c|}
\hline $\begin{array}{l}\text { I would refer patients for abortion services, in situations where I } \\
\text { cannot or will not provide those services myself }(n=252) \text {. }\end{array}$ & $\begin{array}{l}56 \\
(22)\end{array}$ & $\begin{array}{l}27 \\
(11)\end{array}$ & $\begin{array}{l}26 \\
(10)\end{array}$ & $\begin{array}{l}53 \\
(21)\end{array}$ & $\begin{array}{l}90 \\
(36)\end{array}$ \\
\hline $\begin{array}{l}\text { Health care providers who conscientiously object to abortion } \\
\text { should be required to refer patients seeking an abortion to non- } \\
\text { objecting providers }(n=252) \text {. }\end{array}$ & $\begin{array}{l}64 \\
(25)\end{array}$ & $\begin{array}{l}38 \\
(15)\end{array}$ & $\begin{array}{l}39 \\
(16)\end{array}$ & $\begin{array}{l}52 \\
(21)\end{array}$ & $\begin{array}{l}59 \\
(23)\end{array}$ \\
\hline
\end{tabular}

The mean score of the respondents in the subscales for general and conditional support of abortion provision was $2.8(\mathrm{Cl} 2.65-2.99)$ and $2.86(2.75-2.96)$ respectively. The mean score for scale generally not in support of abortion service provision was 2.71 ( $\mathrm{Cl}$ 2.54-2.87). Meanwhile, the mean score for personal attitude and beliefs against and towards abortion service provision was well above the average $3.239(\mathrm{Cl} 3.12-3.35)$ and $3.35(\mathrm{Cl} 3.04-3.35)$ respectively (Table 5). 
In the sub-scale 1, attitude generally in support for abortion service provision, nearly half $115(46 \%)$ of the respondents agree that provision of safe voluntary abortion should be made legal and accessible meanwhile $122(48 \%)$ disagreed with the idea. About $38 \%$ of the respondents agree with the idea of including abortion services as part of the minimum health care package, this is contrary to $52 \%$ who disagree with that provision. Although $43 \%$ of the respondents agree that a woman has a right to decide whether or not to abort, $53 \%$ disagree with the idea. (Table 5).

Subscale 2, attitude generally not in support of abortion had two items. Half of the respondents (50\%) reported that its morally unacceptable for a woman to abort irrespective of any reason, contrary to this, about $71 \%$ of the respondents agree that abortion services should not be provided for any reason but for very good reasons (Table 5).

In sub-scale 3, conditional support for abortion provision, the respondents had a varying opinion for legal provision of abortion depending on the conditions; $81 \%$ of the respondents reported agreement if the woman's physical health is endangered, $65 \%$ if the mental health is endangered, and $71 \%$ if the fetus shows serious congenital anomalies. On the other hand, respondents reported that abortion services should not be provided in the case the woman was raped(49\%), a woman is not married(78\%), the woman is not able to raise the child $(71 \%)$, the pregnancy was a result of incest (58\%), the woman had to drop out of school (69\%) and unplanned pregnancy(65\%) (Table 5).

In sub-scale 4, personal attitudes and beliefs against abortion service provision, nearly half of the respondents $48 \%$ agreed that they will not perform an abortion under any circumstance, meanwhile, $42 \%$ disagreed; $56 \%$ claimed they would not refer a patient for abortion under any circumstances, $35 \%$ agreed for such referral. More than half of the respondents (69\%) reported they would discourage women from seeking abortion procedure, and about $(53 \%)$ said they would discourage other healthcare providers from providing such services. About half $(50 \%)$ of the respondents agreed that abortion service provision is a source of stigma/ discrimination, and (54\%) said that health care providers who conscientiously object abortion service provision should be allowed to say no to it (Table 5).

In sub-scale 5, personal attitudes and beliefs towards abortion provision, more than half of the respondents (57\%) agreed to refer patients for the services only if they cannot can-not or will not provide the services themselves, and about $43 \%$ said the objecting providers should be required to refer patients seeking abortion provision to non-objecting providers (Table 5).

\section{Multivariate Findings}


Table 6

Demographic characteristics associated with adequate knowledge about complications due to unsafe abortions

\begin{tabular}{|c|c|c|c|c|c|c|c|}
\hline $\begin{array}{l}\text { Variables (adequate knowledge n } \\
=162,64 \%, 95 \% 58-70 \% \text { ) }\end{array}$ & Frequency & COR & $\begin{array}{l}95 \% \\
\mathrm{Cl}\end{array}$ & $\begin{array}{l}\mathrm{p}- \\
\text { value }\end{array}$ & AOR & $\begin{array}{l}95 \% \\
\mathrm{Cl}\end{array}$ & $\begin{array}{l}\text { p- } \\
\text { value }\end{array}$ \\
\hline \multicolumn{8}{|l|}{ Gender $(n=252)$} \\
\hline Male & 80 & 1 & & & & & \\
\hline Female & 172 & 0.69 & $\begin{array}{l}0.39- \\
1.22\end{array}$ & 0.198 & 0.75 & $\begin{array}{l}0.34- \\
1.65\end{array}$ & 0.475 \\
\hline \multicolumn{8}{|l|}{ Age group $(n=252)$} \\
\hline Less than 20 years & 25 & 1 & & & 1 & & \\
\hline $20-29$ years & 109 & 2.13 & $\begin{array}{l}0.88- \\
5.18\end{array}$ & 0.094 & 2.07 & $\begin{array}{l}0.74- \\
5.76\end{array}$ & 0.165 \\
\hline $30-39$ years & 78 & 4.35 & $\begin{array}{l}1.69- \\
11.22\end{array}$ & 0.002 & 2.50 & $\begin{array}{l}0.75- \\
8.31\end{array}$ & 0.136 \\
\hline 40 and above years & 40 & 4.50 & $\begin{array}{l}1.54- \\
13.17\end{array}$ & 0.006 & 2.69 & $\begin{array}{l}0.73- \\
10.00\end{array}$ & 0.138 \\
\hline \multicolumn{8}{|l|}{ Marital status $(n=252)$} \\
\hline Single/Separated/Widowed & 101 & 1 & & & 1 & & \\
\hline Cohabiting & 35 & 2.06 & $\begin{array}{l}0.91- \\
4.64\end{array}$ & 0.082 & 1.89 & $\begin{array}{l}0.73- \\
4.94\end{array}$ & 0.192 \\
\hline Married & 116 & 2.70 & $\begin{array}{l}1.53- \\
4.78\end{array}$ & 0.001 & 2.24 & $\begin{array}{l}1.06- \\
4.76\end{array}$ & $0.035^{\star}$ \\
\hline
\end{tabular}

\section{Religion $(n=252)$}

Catholic

Anglican

Born again Christian

others (Muslim/Seventh Days

Adventists/Nonbelievers)

\section{Employment status $(\mathrm{n}=\mathbf{2 5 1})$}

Employed in Government only

Employed in NGO Health Centre
140

59

42

11

$40 \quad 1$

1

1

$\begin{array}{llllll}2.43 & \begin{array}{l}1.20- \\ 4.90\end{array} & 0.013 & 2.22 & \begin{array}{l}1.03- \\ 4.79\end{array} & 0.042^{*}\end{array}$

$\begin{array}{lllllll} & 1.24 & 0.60- & 0.561 & 1.14 & 0.51- & 0.749 \\ 2.53 & & & 2.58 & \\ 1 & 0.82 & 0.24- & 0.759 & 0.94 & 0.24- & 0.935 \\ & & 2.83 & & & 3.77 & \end{array}$




\begin{tabular}{|c|c|c|c|c|c|c|c|}
\hline $\begin{array}{l}\text { Variables (adequate knowledge n } \\
=162,64 \%, 95 \% 58-70 \% \text { ) }\end{array}$ & Frequency & COR & $\begin{array}{l}95 \% \\
\mathrm{Cl}\end{array}$ & $\begin{array}{l}\mathrm{p}- \\
\text { value }\end{array}$ & AOR & $\begin{array}{l}95 \% \\
\mathrm{Cl}\end{array}$ & $\begin{array}{l}\mathrm{p}- \\
\text { value }\end{array}$ \\
\hline $\begin{array}{l}\text { Employed in Private For-Profit } \\
\text { Hospital }\end{array}$ & 44 & 0.89 & $\begin{array}{l}0.40- \\
1.98\end{array}$ & 0.774 & 0.81 & $\begin{array}{l}0.30- \\
2.15\end{array}$ & 0.665 \\
\hline $\begin{array}{l}\text { Employed in private non for-Profit } \\
\text { Hospital }\end{array}$ & 75 & 0.26 & $\begin{array}{l}0.14- \\
0.50\end{array}$ & 0.000 & 0.31 & $\begin{array}{l}0.14- \\
0.66\end{array}$ & $0.002 *$ \\
\hline $\begin{array}{l}\text { Employed in Both Government } \\
\text { and Private Hospitals }\end{array}$ & 6 & 0.67 & $\begin{array}{l}0.12- \\
3.86\end{array}$ & 0.651 & 0.77 & $\begin{array}{l}0.10- \\
5.82\end{array}$ & 0.800 \\
\hline
\end{tabular}

\begin{tabular}{|llllllll|}
\hline $\begin{array}{l}\text { Variables (adequate knowledge } n= \\
162,64 \%, 95 \% 58-70 \%)\end{array}$ & Frequency & COR & $\begin{array}{l}95 \% \\
\mathrm{Cl}\end{array}$ & $\begin{array}{l}\mathrm{p}- \\
\text { value }\end{array}$ & AOR & $\begin{array}{l}95 \% \\
\mathrm{Cl}\end{array}$ & $\begin{array}{l}\mathrm{p}- \\
\text { value }\end{array}$ \\
\end{tabular}

\section{Type of health care provider $(n=$ 251)}

\begin{tabular}{|c|c|c|c|c|c|c|c|}
\hline Nurse & 85 & 1 & & & 1 & & \\
\hline Midwives & 86 & 0.65 & $\begin{array}{l}0.35- \\
1.21\end{array}$ & 0.178 & 0.54 & $\begin{array}{l}0.26- \\
1.12\end{array}$ & 0.100 \\
\hline Doctor & 26 & 2.18 & $\begin{array}{l}0.74- \\
6.36\end{array}$ & 0.156 & 1.24 & $\begin{array}{l}0.37- \\
4.11\end{array}$ & 0.725 \\
\hline Clinical Officer & 30 & 2.59 & $\begin{array}{l}0.90- \\
7.47\end{array}$ & 0.078 & 1.79 & $\begin{array}{l}0.52- \\
6.24\end{array}$ & 0.358 \\
\hline Others & 24 & 0.52 & $\begin{array}{l}0.21- \\
1.30\end{array}$ & 0.160 & 0.38 & $\begin{array}{l}0.12- \\
1.14\end{array}$ & 0.084 \\
\hline
\end{tabular}

\section{Numbers of years working $(n=$ 251)}

\begin{tabular}{|c|c|c|c|c|c|c|c|}
\hline Less than one (1) year & 45 & 1 & & & 1 & & \\
\hline 1 to 5 years & 109 & 1.59 & $\begin{array}{l}0.79- \\
3.20\end{array}$ & 0.197 & 0.65 & $\begin{array}{l}0.27- \\
1.60\end{array}$ & 0.349 \\
\hline 6 to 10 years & 51 & 3.48 & $\begin{array}{l}1.43- \\
8.45\end{array}$ & 0.006 & 1.00 & $\begin{array}{l}0.29- \\
3.41\end{array}$ & 0.994 \\
\hline 11 years and above & 46 & 1.98 & $\begin{array}{l}0.85- \\
4.62\end{array}$ & 0.116 & 0.55 & $\begin{array}{l}0.16- \\
1.94\end{array}$ & 0.352 \\
\hline
\end{tabular}

*Significant

Multivariate logistic regression for an association between demographic characteristics and adequate knowledge about complications due to unsafe abortions revealed that respondents who are married and an Anglican were more likely to be knowledgeable about abortion complication p-values; [0.035( OR 2.24, $\mathrm{Cl}-1.06-4.76)]$ and [0.042(OR 2.22, $\mathrm{Cl} 1.03-4.79)]$ respectively. Meanwhile being employed in Non-For- 
Profit Faith-based hospitals is statistically associated with poor knowledge of abortion complications $\mathrm{p}$ value [0.002(OR, $0.31 \mathrm{Cl} 0.14-0.66)]$ (Table 6).

Table 7:

Ordinary least square regression analysis

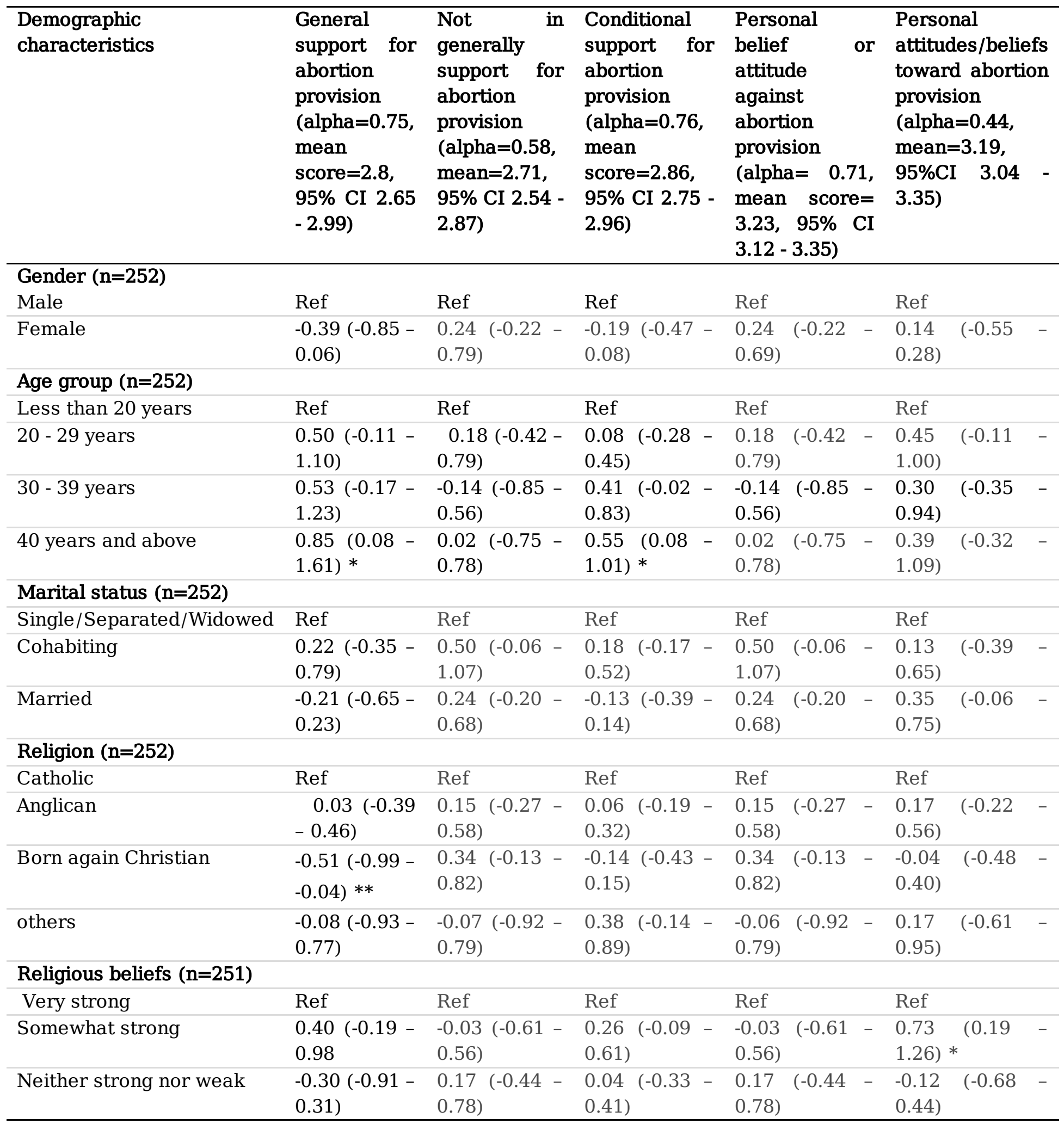




\begin{tabular}{|c|c|c|c|c|c|}
\hline $\begin{array}{l}\text { Demographic } \\
\text { characteristics }\end{array}$ & $\begin{array}{l}\text { General } \\
\text { support for } \\
\text { abortion } \\
\text { provision } \\
\text { (alpha=0.75, } \\
\text { mean }\end{array}$ & $\begin{array}{l}\text { Not in generally } \\
\text { support for } \\
\text { abortion } \\
\text { provision } \\
\text { (alpha }=0.58 \text {, } \\
\text { mean }=2.71 \text {, }\end{array}$ & $\begin{array}{l}\text { Conditional } \\
\text { support for } \\
\text { abortion } \\
\text { provision } \\
\text { (alpha=0.76, } \\
\text { mean }\end{array}$ & $\begin{array}{l}\text { Personal belief or } \\
\text { attitude } \\
\text { abortion } \\
\text { against } \\
\text { (alpha= } \\
\text { mean score }=3.23 \text {, } \\
95 \% \text { CI } 3.12-3.35 \text { ) }\end{array}$ & $\begin{array}{l}\text { Personal } \\
\text { attitudes/beliefs } \\
\text { toward abortion } \\
\text { provision } \\
\text { (alpha=0.44, } \\
\text { mean=3.19, }\end{array}$ \\
\hline & $\begin{array}{l}\text { score }=2.8,95 \% \\
\text { CI } 2.65-2.99)\end{array}$ & $\begin{array}{l}95 \% \text { CI } 2.54 \quad- \\
2.87)\end{array}$ & $\begin{array}{l}\text { score }=2.86, \\
95 \% \text { CI } 2.75- \\
2.96)\end{array}$ & & $\begin{array}{lll}95 \% \text { CI } & 3.04 \\
3.35) & \end{array}$ \\
\hline
\end{tabular}

\section{Employment}

status

$(\mathrm{n}=251)$

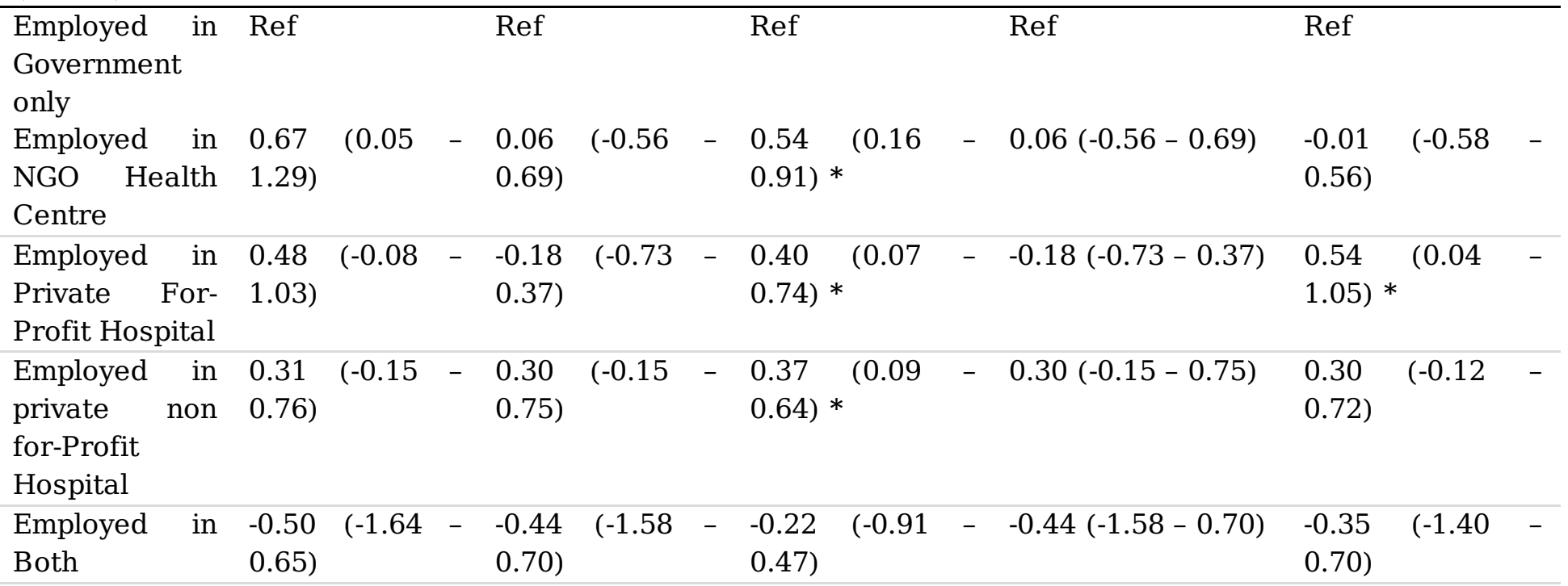

Type of health care provider

$(\mathrm{n}=251)$

\begin{tabular}{|c|c|c|c|c|c|c|c|c|c|c|c|c|c|}
\hline Nurse & Ref & & & Ref & & & Ref & & & Ref & Ref & & \\
\hline Midwives & $\begin{array}{l}0.06 \\
0.48)\end{array}$ & $(-0.37$ & - & $\begin{array}{l}-0.04 \\
0.38)\end{array}$ & $(-0.47$ & - & $\begin{array}{l}-0.02 \\
0.23)\end{array}$ & $(-0.28$ & - & $-0.04(-0.47-0.38)$ & $\begin{array}{l}0.25 \\
0.65)\end{array}$ & $(-0.14$ & - \\
\hline Doctor & $\begin{array}{l}-0.11 \\
0.54)\end{array}$ & $(-0.77$ & - & $\begin{array}{l}0.20 \\
0.85)\end{array}$ & $(-0.46$ & - & $\begin{array}{l}-0.06 \\
0.34)\end{array}$ & $(-0.45$ & - & $0.20(-0.46-0.85)$ & $\begin{array}{l}-0.24 \\
0.36)\end{array}$ & $(-0.84$ & - \\
\hline $\begin{array}{l}\text { Clinical } \\
\text { Officer }\end{array}$ & $\begin{array}{l}-0.09 \\
0.58)\end{array}$ & $(-0.76$ & - & $\begin{array}{l}-0.17 \\
0.50)\end{array}$ & $(-0.84$ & - & $\begin{array}{l}0.28 \\
0.69)\end{array}$ & $(-0.12$ & - & $-0.17(-0.84-0.50)$ & $\begin{array}{l}0.28 \\
0.90)\end{array}$ & $(-0.33$ & - \\
\hline Others & $\begin{array}{l}-0.10 \\
0.58)\end{array}$ & $(-0.78$ & - & $\begin{array}{l}-0.35 \\
0.33)\end{array}$ & $(-1.03$ & - & $\begin{array}{l}-0.02 \\
0.39)\end{array}$ & $(-0.43$ & - & $-0.35(-1.03-0.33)$ & $\begin{array}{l}0.07 \\
0.70)\end{array}$ & $(-0.55$ & - \\
\hline $\begin{array}{l}\text { Number of } \\
(n=251)\end{array}$ & years & worki & & & & & & & & & & & \\
\hline $\begin{array}{l}\text { Less than one } \\
\text { (1) year }\end{array}$ & Ref & & & Ref & & & Ref & & & Ref & Ref & & \\
\hline 1 to 5 years & $\begin{array}{l}-0.12 \\
0.42)\end{array}$ & $(-0.66$ & - & $\begin{array}{l}-0.45 \\
0.09)\end{array}$ & $(-0.99$ & - & $\begin{array}{l}0.08 \\
0.40)\end{array}$ & $(-0.25$ & - & $-0.45(-0.99-0.09)$ & $\begin{array}{l}-0.00 \\
0.49)\end{array}$ & $(-0.50$ & - \\
\hline 6 to 10 years & $\begin{array}{l}-0.14 \\
0.57)\end{array}$ & $(-0.86$ & - & $\begin{array}{l}-0.46 \\
0.25)\end{array}$ & $(-1.18$ & - & $\begin{array}{l}-0.14 \\
0.29)\end{array}$ & $(-0.57$ & - & $-0.46(-1.18-0.25)$ & $\begin{array}{l}0.06 \\
0.72)\end{array}$ & $(-0.60$ & - \\
\hline $\begin{array}{l}11 \text { years and } \\
\text { above }\end{array}$ & $\begin{array}{l}-0.25 \\
0.50)\end{array}$ & $(-0.99$ & - & $\begin{array}{l}-0.25 \\
0.49)\end{array}$ & $(-0.99$ & - & $\begin{array}{l}-0.25 \\
0.19)\end{array}$ & $(-0.70$ & - & $-0.25(-0.99-0.49)$ & $\begin{array}{l}0.02 \\
0.70)\end{array}$ & $(-0.66$ & - \\
\hline Intercept & $\begin{array}{l}2.60 \\
3.44)\end{array}$ & $(1.76$ & - & $\begin{array}{l}2.56 \\
3.40)\end{array}$ & $(1.73$ & - & $\begin{array}{l}2.51 \\
3.02)\end{array}$ & $(2.00$ & - & $2.56(1.73-3.40)$ & $\begin{array}{l}2.36 \\
3.12)\end{array}$ & $(1.59$ & - \\
\hline djusted R2 & 0.12 & & & -0.002 & & & 0.10 & & & 0.09 & 0.03 & & \\
\hline
\end{tabular}


In ordinary least-square regression analysis, being of aged 40 years and above was positively associated with general support for abortion provision and conditional support for abortion provision (coefficients 0.85 and 0.55 ). Participants who had strong religious beliefs were positively associated with personal attitudes/beliefs towards abortion provision (coefficient 0.73 ). Being employed in the NGO Health facility was positively associated with general support for abortion provision and conditional support for abortion provision (coefficients 0.67 and 0.54 ). While being employed in a private for-profit health facility was positively associated with conditional support for abortion providers and personal attitudes/beliefs towards abortion provision (coefficients 0.40 and 0.54). Similarly, being a participant who was employed in a private not for profit faith-based health facility was positively associated with conditional support for abortion provision (coefficient 0.37 ). However, being a born-again Christian was negatively associated with general support for abortion provision (coefficient -0.51). Table 7 summarises the result for the five scales of abortion attitude.

\section{Discussion}

To the best of our knowledge, this is the first study investigating knowledge, practice, and attitude of healthcare providers as in regard to abortion service provision in Northern Uganda. The respondents were drawn from a wide background of the healthcare professional within, Gulu City, northern Uganda.

Regarding knowledge about abortion complications, respondents employed in faith-based health facilities showed comparatively lower knowledge of complications caused by induced abortion [p-value 0.002 (OR, $0.31 \mathrm{Cl} 0.14-0.66$ ). The gap in Knowledge among respondents could be related to unavailability of training opportunities and post-abortion service provision as most faith-based facilities do not provide abortion services except as part of the emergency evacuation for inevitable or incomplete abortion. Mother church positions on abortion are normally that of pro-life hence less or no involvement of their staffs in post-abortion and comprehensive abortion care-related pieces of training. Post-abortion care training exposes healthcare providers to value clarification and attitude transformation (VCAT), a very important tool in clarifying about abortion service provision in some circumstances(17). Exposure and training may also explain a positive association about providers who are 40 years and older and an employed in Non-for-profit NGO health facilities in general support for abortion provision, coefficients 0.85 and 0.67 respectively. Post-abortion care-related pieces of training can enhance conditional support for abortion provision as seen by positive association among providers who are aged 40 years or more, employed in NGO and private for-profit health facilities and conditional support for abortion provision coefficients $0.55,0.54$, and 0.4 respectively. This finding is similar to a study conducted in Pakistani by Baig (2017) which found about $60 \%$ of the midlevel health care providers showed a positive attitude to 
value clarification regarding post-abortion care because of religious influence, abortion being a sinful act in the Islam religion,(18). Meanwhile, being a born-again Christian was negatively associated with general support for abortion provision (coefficient -0.51 ). This finding replicates a national survey about knowledge and perception of abortion law in Trinidad and Tobago revealed that Christians who are NonCatholics and non-Pentecostals are more of prochoice compared to Catholics and Pentecostal who are antichoice(19).

Most of the respondents (85\%) were aware of the use of modern family contraceptives as a good method of preventing post-abortion complications. This is particularly important in Ugandan settings where a significant number of pregnancies are unintended and stems from low contraceptive uptake; a prevalence of $35 \%$ and high unmet needs of contraceptive(28\%)(12). Training healthcare providers in post-abortion family planning services is a perfect opportunity for intervention used to increase modern post-abortion contraceptives uptake.

Although a good number of respondents (69\%) believed that many of the induced abortions are done by unmarried couples, up to (59\%) did say that avoiding sex before marriage is not a solution to preventing complications due to unsafe abortion. Because of Uganda's restrictive abortion laws, many women or couples with unintended pregnancies seek a clandestine, unsafe abortion. This practice may be higher in some societies where premarital sex is regarded as a sin and can lead to social ostracization.

Interventions aimed at reducing unwanted pregnancies among sexually active unmarried women will help lessen the complications of induced abortion. This is consistent with earlier findings in Uganda where the contraceptive increase has been seen as a way to reduced maternal mortality and morbidity caused by unsafe abortion(20).

Nearly half (49\%) of the respondents hoped for a change in the abortion laws in Uganda yet the majority (61\%) detest legalizing abortion laws. Article 22(2) of the Ugandan Constitution, "protection of the right to life," states, "no person has the right to terminate the life of an unborn child except as may be authorized by law" (21). This provision does not exclude access to abortion, it simply requires that there is no right on the part of any person whether the provider or the pregnant woman to terminate "the life of an unborn child" in the dearth of a law permitting them to do so. This may be because of the confusion about the laws that have already some provision for termination of pregnancy in case of severe congenital anomalies and danger to maternal life. The legalization of abortion laws might attract widespread resistance from pro-life movement and such a law might never be passed. It also enlightens the controversies around abortion care as stated by the Ugandan opinion leaders (14).

The confusion continues to disintegrate the minds of the study respondents giving out mixed reactions, about $49 \%$ of the respondents disagreed with the legal provision of abortion in a condition that the woman was raped, meanwhile $40 \%$ agreed that if the pregnancy was as a result of rape then she may terminate the pregnancy. This, however, maybe as a result of personal perceptions of rape and incest being an abomination in the African society, pregnancy occurring as a result of this is considered "a bad 
luck child" who may bring misfortune to the family, while others attach this to religious belief that every child is a gift to the family irrespective of the circumstances around it as found elsewhere(22).

About half $(50 \%)$ of the study respondents reported stigma related to abortion care provision, this could be due to unclear laws on induced abortion in Uganda and the moral values among healthcare providers making them reluctant to commit to abortion-related care. Stigma and passive resistance are key barriers to the realization of reproductive health including abortion-related care in Northern Uganda as has been reported elsewhere (23). The level of stigma seems to be similar across all sections of the community as motorbike taxi drivers (Boda Boda) expressed a great deal of tension and conflict over abortion as it relates to notions of respectability, family shame, felt it was necessary to dissociate themselves from the practice in public spaces yet in private spaces they reported being involved in abortions (24).

Participants who had strong religious beliefs and those who are employees in the private for-profit health facilities were positively associated with personal attitudes/beliefs towards abortion provision coefficient 0.73 and 0.54 , respectively. Two items were examined under this subscale about the referral of a patient for abortion services only if they cannot or will not provide the services themselves, and about objecting healthcare providers that should refer patients seeking abortion services provision to non-objecting providers. This is a reassuring finding given the fact that these providers are more likely to refer clients seeking abortion-related services ensuring continuity of care.

The Ugandan penal code has provision for abortion in the event that the pregnancy is causing harm to the mother or the baby has severe congenital anomalies incompatible with life(25). There was no mention of conscientious objection whether in the constitution or penal code, in case a healthcare provider has been faced with a mother who meets criteria for pregnancy termination as provided in the laws, under what circumstances are they supposed to object if they feel it is against their beliefs or values. A South African study involving in-depth interviews among healthcare providers clearly brought the lack of understanding concerning the circumstances in which health care providers were entitled to invoke their right to refuse to provide or assist in abortion services. Providers seemed to have poor understandings of how conscientious objection was to be implemented, but was also constrained in that there were few guidelines or systems in place to guide them in the process(26).

This study has several limitations. First, responses from a self-administered survey may not be indicative of the actual behaviour, particularly regarding current and future intentions and behaviour. Furthermore, external issues, such as facility-based constraints preventing abortion provision, may be restraints to access to abortion services now and in the future, despite the providers' attitude and willingness to perform or not abortions related services. A comprehensive longitudinal assessment of practices and beliefs requiring a large-scale cohort study among providers in various health facilities in Uganda will give more information.

Second, given the restrictive nature of abortion laws in Ugandan settings and despite all efforts to ensure confidentiality, providers' response may be biased by socio-cultural and legal norms and dependent on the degree to which each individual respondent felt comfortable stating attitudes and practices contrary 
to such standards. We attempted to minimize such bias by administering the questionnaire privately and anonymously.

A third limitation is that our findings may not be generalizable to other healthcare providers in Uganda or other countries. Healthcare providers in Gulu City may differ demographically or otherwise in Uganda or elsewhere. Knowledge, attitudes, and beliefs about abortion and abortion provision can be quite different from country to country and should be considered in the appropriate political, religious, cultural, and educational context.

We believe our study is the first to look at the knowledge attitudes of healthcare providers as regards abortion provision in Uganda. We achieved a high level of response by recruiting providers from department to department through their supervisors. An additional strength is an instrument itself, which

was designed carefully, the attitudinal score being adopted from the South African study, and modified to fit for our case(16), piloted extensively, and tested for internal reliability and consistency.

\section{Conclusion}

Post-abortion and comprehensive abortion care training with VCAT is key interventions to help improve on the attitude of healthcare providers especially those working in reproductive healthcare points as they manage clients seeking post-abortion care including termination of pregnancy when medically indicated. Such healthcare workers may need to have basic understandings of the situations under which some women chose to terminate a pregnancy or seek post-abortion care if they are to provide an objective harm reduction strategy. Effective ways to improve access to harm reduction strategy in abortion care must be carefully planned, applied, and repeatedly monitored and evaluated.

A clear national effort to improve abortion training and service delivery is needed and must involve private and public practitioners, ministry of health, academic training and research institutions, and nongovernmental health organizations.

Academic medical institutions must ensure that students understand the laws and responsibilities that govern their professional actions with respect to abortion care (regardless of their personal views) and must provide appropriate abortion training.

Training and service in post-abortion family planning should be increased to meet the family needs and reduce the unintended pregnancy rates in Uganda. Larger and nationwide additional studies examining the knowledge, attitudes, beliefs, and intentions of providers in abortion provision would be an important contribution to the field.

\section{List Of Abbreviations}

AOGU: Association of Obstetricians and Gynaecologists of Uganda; CPR: Contraceptive Prevalence Rate; UDHS: Uganda Demographic Health Survey; GUREC: Gulu University Research and Ethics committee; 
LHIREC: Lacor Hospital Institutional Research and Ethics Committee; NGO: Non-Government Organisation; PI: Principle Investigator; TFR: Total Fertility Rate; VCAT: Value Clarification and Attitude Transformation

\section{Declarations}

\section{Ethics approval and consent to participate}

Approval to carry out this research was sought from: Gulu University Research Ethics Committee approved the study under number GUREC-079-19. and each individual research participants provided written informed consent before participation in the study. Administrative clearances were granted by Gulu Regional Referral Hospital ethical committee correspondence number ADM/2017-18/001 and St Mary's Hospital Lacor ethical boards with administrative clearance number LHIREC Adm 022/09/19. Marie Stopes Uganda provided an email clearance, other Health centres, and hospitals provided administrative clearance verbally by each institutional head before we recruited the participants into the survey.

\section{Consent to Publish}

Not Applicable

\section{Availability of Data and Materials}

The data sets used and analysed during this study are not deposited in the public repository but available from the corresponding author on reasonable request.

\section{Competing Interests}

The authors declare that they have no competing interests

\section{Funding}

This study was funded by the Safe Abortion Advocacy project by the Association of Obstetricians and Gynaecologists of Uganda (AOGU). The funders had no role in study design, data collection, and interpretation of data and in writing the manuscript.

\section{Author's Contributions}

All authors contributed significantly to this work. PFP; Conceived, designed the study, participated in data collection, interpretation, and discussion; drafted the manuscript. AAG.; participated in the proposal designs, data interpretation, and discussion. OJH participated in drafting the method, data analysis and interpretation. All Authors read and approved the manuscript. 
Acknowledgments

Not Applicable

\section{References}

1. WHO. Unsafe Abortion: Global and Regional Estimates of the Incidence of Unsafe Abortion and Associated Mortality in 2008. Geneva, Switzerland: World Health Organization; 2011.

2. Singh S. Global Consequences of Unsafe Abortion. Women's Health. 2010;6(6):849-60.

3. Gebremedhin M, Semahegn A, Usmael T, Tesfaye G. Unsafe abortion and associated factors among reproductive aged women in Sub-Saharan Africa: a protocol for a systematic review and metaanalysis. Systematic Reviews. 2018;7(1):130.

4. Ganatra B, Gerdts C, Rossier C, Johnson BR, Jr., Tunçalp Ö, Assifi A, et al. Global, regional, and subregional classification of abortions by safety, 2010-14: estimates from a Bayesian hierarchical model. Lancet. 2017;390(10110):2372-81.

5. Assefa EM. Knowledge, attitude and practice (KAP) of health providers towards safe abortion provision in Addis Ababa health centers. BMC Women's Health. 2019;19(1):138.

6. Sully EA, Atuyambe L, Bukenya J, Whitehead HS, Blades N, Bankole A. Estimating abortion incidence among adolescents and differences in postabortion care by age: a cross-sectional study of postabortion care patients in Uganda. Contraception. 2018;98(6):510-6.

7. Prada E, Atuyambe LM, Blades NM, Bukenya JN, Orach CG, Bankole A. Incidence of Induced Abortion in Uganda, 2013: New Estimates Since 2003. PLOS ONE. 2016;11(11):e0165812.

8. Mohamed SF, Izugbara C, Moore AM, Mutua M, Kimani-Murage EW, Ziraba AK, et al. The estimated incidence of induced abortion in Kenya: a cross-sectional study. BMC Pregnancy and Childbirth. 2015;15(1):185.

9. Basinga P, Moore AM, Singh S, Remez L, Birungi F, Nyirazinyoye L. Unintended Pregnancy and Induced Abortion in Rwanda: Causes and Consequences, New York: Guttmacher Institute, 2012.; 2012.

10. Keogh SC, Kimaro G, Muganyizi P, Philbin J, Kahwa A, Ngadaya E, et al. Incidence of Induced Abortion and Post-Abortion Care in Tanzania. PloS one. 2015;10(9):e0133933-e.

11. Uganda MoHM. Road Map for Accelerating the Reduction of Maternal and Neonatal Mortality and Morbidity in Uganda 2006-2015. 2008.

12. UDHS UBoSUal. Uganda Demographic and Health Survey 2016: Key Indicators Report. Kampala, Uganda: UBOS, and Rockville, Maryland, USA: UBOS and ICF. . 2017.

13. Jarolimova J, Kabakyenga J, Bennett K, Muyindike W, Kembabazi A, Martin JN, et al. Contraceptive use following unintended pregnancy among Ugandan women living with HIV. PLOS ONE. 2018;13(10):e0206325. 
14. Moore AM, Kibombo R, Cats-Baril D. Ugandan opinion-leaders' knowledge and perceptions of unsafe abortion. Health Policy Plan. 2014;29(7):893-901.

15. Paxman JM, Rizo A, Brown L, Benson J. The Clandestine Epidemic: The Practice of Unsafe Abortion in Latin America. Studies in Family Planning. 1993;24(4):205-26.

16. Stephanie B. Wheeler LLZ, Bryce B. Reeve, Geoffrey A. Buga, and Chelsea Morroni. Attitudes and Intentions Regarding Abortion Provision Among Medical School Students in South Africa. Int Perspect Sex Reprod Health. 2012;38(3):154-63.

17. Turner KL, Pearson E, George A, Andersen KL. Values clarification workshops to improve abortion knowledge, attitudes and intentions: a pre-post assessment in 12 countries. Reproductive Health. 2018;15(1):40.

18. Baig M, Jan, R, Lakhani, A, Ali, S A, Mubeen, K, Ali, S S, \& Adnan, F. Knowledge, Attitude, and Practices of Mid-Level Providers regarding Post Abortion Care in Sindh, Pakistan. Journal of Asian Midwives. 2017;4(1):21-34.

19. Martin CJ, Hyacenth G, Suite LS. Knowledge and Perception of Abortion and the Abortion Law in Trinidad and Tobago. Reproductive Health Matters. 2007;15(29):97-107.

20. Gorrette N, Nabukera S, Salihu HM. The abortion paradox in Uganda: Fertility regulator or cause of maternal mortality. Journal of Obstetrics and Gynaecology. 2005;25(8):776-80.

21. Constitution U. The 1995 Constitution 1995.

22. Rakhudu M, Mmelesi A, Myburgh C, Poggenpoel M. Exploration of the views of traditional healers regarding the termination of pregnancy (TOP) law. Curationis. 2006;29(3):56-60.

23. Mitchell EM TK, Gabriel MC, Fine A, Manentsa N,: . Accelerating the Pace of Progress in South Africa: An Evaluation of the Impact of Values Clarification workshops on Termination of Pregnancy Access Limpopo Province Limpopo Province Chapel Hill, NC:: Ipas; 2005.

24. Nyanzi S, Nyanzi B, Bessie K. "Abortion? That's for women!" Narratives and experiences of commercial motorbike riders in south-western Uganda. Afr J Reprod Health. 2005;9(1):142-61.

25. Uganda Ro. Penal Code Act (CAP 106). Revised Edition ed1984.

26. Harries J, Stinson K, Orner P. Health care providers' attitudes towards termination of pregnancy: A qualitative study in South Africa. BMC Public Health. 2009;9(1):296.

\section{Supplementary Files}

This is a list of supplementary files associated with this preprint. Click to download.

- AbortionstudyDatabase.xlsx 